\title{
PRINCIPIOLOGIA JURÍDICA, HISTÓRIA E COSMOLOGIA GUARANI
}

\author{
LEGAL PRINCIPLE, HISTORY AND COSMOLOGY GUARANI \\ PRINCIPIOLOGÍA JURIDICA, HISTORIA E COSMOLOGÍA GUARANI
}

\author{
Rosalvo Ivarra Ortiz \\ Mestrando em Antropologia Sociocultural \\ Bolsista: FUNDECT/MS \\ Universidade Federal da Grande Dourados \\ rosalvortiz@hotmail.com \\ Brasil
}

Almires Martins Machado

Doutor em Antropologia

Instituto Indígena Brasileiro para a Propriedade Intelectual

ateguara@gmail.com

Brasil

\section{Resumo}

Este artigo aborda o direito Guarani (Kaiowá, Nhandeva e Mbyá), povos indígenas de Dourados, Mato Grosso do Sul, Centro-Oeste do Brasil, a partir de sua principiologia, nuances no trato e subsunção das questões comunitárias. Como dirime os conflitos nos mais diversos campos do direito. Assim aborda a importância que a cosmovisão tem para esse direito nativo, do qual advém o juízo holístico. Discorre sobre os princípios gerais do direito Guarani: a solidariedade, reciprocidade e prevalência do interesse coletivo sobre o individual. Apesar de tratar de direito indígena, o enfoque se detém no direito de propriedade Guarani. Vale-se do aporte teórico sobre o pluralismo jurídico, para sustentá-lo como um sistema jurídico, embora pensado e legislado de forma díspares do Direito nacional. Ao final, adentra-se nos iníquos resultados da intervenção externa, sem os devidos cuidados antropológicos necessários a tais ações, que parte nesse caso de quem tem a incumbência jurisdicional de defender o direito e interesse indígena.

Palavras chave: direito guarani, pluralismo, intervenção, propriedade. 


\begin{abstract}
This article deals with the Guarani law (Kaiowá, Nhandeva and Mbyá), indigenous peoples of Dourados, Mato Grosso do Sul, Central-West of Brazil, from its principles, nuances in the treatment and subsumption of community issues. How to resolve disputes in the most diverse fields of law. Thus he approaches the importance that the worldview has for this native right, from which comes the holistic judgment. It discusses the general principles of Guarani law: solidarity, reciprocity and the prevalence of collective interest over the individual. Although dealing with indigenous law, the focus is on Guarani property rights. It is worth the theoretical contribution on legal pluralism, to support it as a legal system, although thought and legislated differently from national law. In the end, it enters the wicked results of the external intervention, without the necessary anthropological care necessary for such actions, which in this case starts from those who have the jurisdictional responsibility to defend the indigenous right and interest.
\end{abstract}

Keywords: guarani law, pluralism, intervention, property.

\title{
Resumen
}

Este artículo trata sobre el derecho guaraní (Kaiowá, Nhandeva y Mbyá), los pueblos indígenas de Dourados, Mato Grosso do Sul, Centro-Oeste de Brasil, desde su principiología, matices en el tratamiento y subsunción de los problemas comunitarios. Cómo resuelve conflictos en los más diversos campos del derecho. Por lo tanto, aborda la importancia que tiene la cosmovisión para este derecho nativo, del cual proviene el juicio holístico. Discute los principios generales del derecho guaraní: la solidaridad, la reciprocidad y la prevalencia del interés colectivo sobre el individuo. Aunque el artículo trate del derecho indígena, el enfoque está en los derechos de propiedad guaraníes. Hace uso del aporte teórico sobre el pluralismo jurídico, para apoyarlo como un sistema legal, aunque pensado y legislado de manera diferente al derecho nacional. Al final, se profundiza en los resultados inicuos de la intervención externa, sin la atención antropológica necesaria para tales acciones, lo que deja en este caso a quienes tienen la responsabilidad jurisdiccional de defender los derechos e intereses indígenas.

Palabras clave: derecho guaraní, pluralismo, intervención, propiedad. 


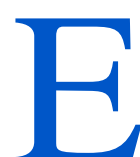

mbora os direitos dos cidadãos brasileiros estejam previstos na Constituição Federal de 1988, para o cidadão indígena, o Direito ainda não é algo palpável, ao alcance das mãos, que o socorra quando da necessidade de remédio judicial; é para trilhar esse caminho de invisibilidade do Direito para os povos indígenas, que apresento a proposta a seguir, orientada pela pluralidade jurídica.

A dualidade de ambientes: o espaço de convivência de uma comunidade indígena e o espaço de convivência fora da aldeia seja rural ou urbano, e o direito prevalente nesses espaços permite um olhar mais acurado, crítico. O Direito nacional nem sempre é aplicado para que o indígena seja sujeito de direitos, ele existe na teoria, mas como ferramenta jurídica é algo que ainda precisa ser regulamentado, principalmente o artigo $4^{\circ}$ do Código Civil de 2002, quando remete a capacidade civil do indígena à legislação especial.

O Estatuto do Índio ou a lei n6.001/1973, no título VI, das normas penais, artigo 57, prevê a tolerância quando da aplicação de sanções penais ou disciplinares aos seus membros pelos grupos tribais, desde que não se revestisse de caráter cruel, infamante ou que fosse a pena de morte.

A questão é: se já aceita a aplicação do direito penal, porque não estender essa aceitação ao ramo do direito entendido como civil, nas comunidades indígenas? Preceitua o mandamento Constitucional que seja respeitado os usos, costumes e tradições dos povos indígenas (caput do art. 231, CF/88). A promulgação da atual Constituição Federal Brasileira, em cujo caput do art. $5^{\circ}$ da $\mathrm{CF} / 88$ se enuncia "o direito de igualdade de todos perante a lei, sem distinção de qualquer natureza", indica que esta é a orientação ao intérprete do direito para que o mesmo pondere sobre o princípio da igualdade, quando estiverem em questão os direitos fundamentais do homem. Porquanto, a República Federativa do Brasil tem como um dos de seus objetivos fundamentais “(...) reduzir as desigualdades sociais e regionais (art. $3^{\circ}, \mathrm{IV}, \mathrm{CF} / 88$ ).

As constituições brasileiras, desde o império, cuidam da igualdade como a igualdade formal, é a igualdade perante a lei, que pressupõe não dispensar a ninguém tratamento que tenha a pretensão de tão somente nivelar o ser humano, os cidadãos do país, à norma legal posta, e esta não pode destoar da isonomia. O sistema jurídico brasileiro ainda não oferece os meios legais para que possam ser solucionadas judicialmente as demandas dos povos indígenas, as que surjam em uma determinada comunidade ou ainda conflitos entre indígenas e outras sociedades. 
O preenchimento dessas lacunas, a aplicação do ordenamento jurídico indígena (cada povo tem o seu Direito específico), na solução de conflitos, é a proposta desta dissertação, porém, toda a discussão versará tendo por viés o Direito de propriedade do Direito Guarani. O norte orientador é a previsão Constitucional, de que devem ser respeitados os usos, costumes e tradições dos povos indígenas, assim como a previsão contida na Convenção 169 da Organização Internacional do Trabalho (OIT).

Há que se atentar para o pluralismo jurídico, a outros modos de juridicidade em operação; o direito pode existir sem o Estado, como é o caso dos povos indígenas, que têm o seu Direito próprio e não precisam do Estado para se organizarem em sociedade. A questão é que comumente se identificava o Direito com o Estado e a consequência é julgar os povos indígenas como não tendo Direito próprio, ficando assim explicitado o etnocentrismo jurídico, típico de Estados modernos de origem colonial.

A Constituição Federal estabelece que o domínio das terras tradicionalmente ocupadas pelos indígenas pertence à União (art. 20, XI); determina competência exclusiva da União para legislar sobre populações indígenas (art. 22, XIV) e reconhece, em capítulo específico (arts. $231 \mathrm{e}$ 232), a organização social, costumes, línguas, crenças e tradições, assim como os direitos originários sobre as terras que tradicionalmente ocupam; o art. 231, CF/88, alberga o direito à alteridade, ou seja, do indígena ser diferente, afirmando que não há uma inferioridade de direitos, por essa razão o direito à diferença não pode ser confundido com incapacidade. Quanto à capacidade civil, os indígenas, em razão de serem considerados como "inferiores", estão sob um regime especial de proteção.

Quando português e espanhol, nas terras da América, se depararam com outra realidade sócio jurídica, surgiram às primeiras grandes dificuldades que persistem até nos dias de hoje: a falta de compreensão e de respeito ao direito do outro; causou-lhes verdadeiro furor mental, hermenêuticojurídico, o Direito nativo que se lhes apresentava, pois era concebido de outra forma e não tinha o Estado como legislador.

Em seguida veio o choque filosófico, por não compreenderem os princípios do Direito indígena, especialmente do Direito Guarani do qual a dissertação trata, que, diferentemente do Direito europeu de tradição romanista, é fundamentado basicamente na responsabilidade coletiva, no sistema de reciprocidade e solidariedade, priorizando os interesses coletivos sobre os individuais.

Esta principiologia indígena apresentava-se absurda ao europeu, cujo Direito prima pelo individualismo, tendo 
como legislador o Estado. O Direito Guarani é coletivo e foi ditado pela cosmologia, onde tudo é interligado e os interesses da comunidade é que prevalecem.

Desta forma, algumas perguntas direcionam a escrita da dissertação: o que é o Direito Indígena? Poderá ser considerado como uma fonte do Direito Estatal ou trata-se de outro Direito? Os usos e costumes indígenas podem ser considerados como Direito ou fonte do Direito? Quais são as bases do Direito indígena?

O presente artigo trata, em específico, do Direito Guarani vigente na Terra Indígena Francisco Horta Barbosa, porém o mesmo é similar ao aplicado nas demais aldeias Guarani e Kaiowa, do estado de Mato Grosso do Sul.

A proposta não é substituir o ordenamento jurídico nacional pelo ordenamento jurídico indígena, mas sim estabelecer balizas para que o segundo auxilie o primeiro na solução de conflitos, preenchendo as lacunas do Direito nacional, por isso o caminho a se percorrer de Direito indigenista a Direito indígena, principalmente quando se tratar do direito de propriedade e esse será o segundo olhar: tentar responder na medida do possível às inquietações do Direito em relação à propriedade nas terras guaranis, que a cada dia se fazem mais presentes no cotidiano dos aplicadores do Direito. O agravante é que se trata de uma terra indígena com superpopulação e o espaço físico reduzido, a terra está cada vez menor.

A construção da dissertação perpassa um caminho imaginário, no qual o sistema jurídico indígena se constitui em uma das margens do caminho e o direito positivo a outra. Os povos indígenas caminham no centro. Portanto, proceder-se-á a uma análise hermenêutica, objetivando discorrer sobre o Direito indígena sustentando-o como um sistema jurídico e desenvolver a principiologia do Direito Indígena Guarani.

O operador do Direito desconhece as normas vigentes e consensuadas em uma comunidade indígena, razão pela qual a interferência junto a estes povos indígenas é danosa, embora pensada pelo intérprete como solução. Não se observa e respeita as diferenças culturais; os limites da interculturalidade, alteridade, dos Direitos Humanos, o que torna o equilíbrio da convivência bastante precário e resulta em conflito declarado.

A metodologia utilizada se valeu de entrevistas com o Guarani, Terena e Kaiowa mais velhos, de depoimentos das lideranças políticas e religiosas. Lembrando que se trata de uma construção coletiva na qual ainda prevalece o código do silêncio, onde, apesar de se ter avançado bastante, há meandros que, como Guarani, me é dado o direito de 
conhecer, porém sobre os quais não me foi permitido discorrer na dissertação.

\section{O contrato interétnico}

No período que antecede a Guerra do Paraguai, a região que corresponde ao atual Estado de Mato Grosso do Sul era povoada somente pelos povos indígenas, havendo alguns núcleos de povoamento de não índios de caráter puramente militar, representados pelo forte Coimbra, a vila de Nossa Senhora da Conceição (Corumbá), a vila de Miranda, em razão da "colônia militar de Miranda" e a povoação de Nioaque. Os núcleos militares de importância eram o forte de Iguatemi e a Colônia Militar de Dourados, localizada na cabeceira do rio Dourados.

No decorrer da Guerra do Paraguai (1864-1870), os povos indígenas que habitavam a fronteira, principalmente $\mathrm{o}$ Guarani que, fugindo do conflito se escondia na floresta, foram novamente forçados a manter contato com o não índio. Seu território foi transformado em campos de batalha, travada entre o exército da tríplice aliança e o paraguaio, sofrendo diretamente os impactos da guerra; ficando entre dois fogos eram eliminados pelos dois exércitos. Os sobreviventes fugiam em busca de lugares ermos onde pudessem viver e plantar as suas roças. Eram estes, entre outros indígenas, que se uniam para enfrentar as adversidades, no novo local de morada.

As três etnias que compunham o contrato interétnico, o Guarani, Terena e o Kaiowa, vinham desta realidade pós-guerra. Enfraquecidos e sem um destino certo se uniram para que então fosse formado um novo tekoha

Esse contrato social encontra eco na afirmação de Rousseau:

Suponho que os homens que chegam a este ponto, em que os obstáculos que impedem a sua conservação no estado de natureza, levam, por sua resistência, para forças que cada indivíduo pode empregar para se manter nesse estado. Esse estado positivo, então, não pode subsistir e $\mathrm{o}$ gênero humano pereceria se não mudasse à sua maneira de ser. Portanto, como os homens não podem engendrar novas forças, mas apenas unir e dirigir as que existem, não possuem outro meio para se conservar, senão formar, por agregação, um conjunto de forças, que possa levar à resistência, empregar um único móvel e fazê-los agir em conformidade com eles. Esta soma de forças não pode nascer senão do concurso de várias: mas sendo a força e a liberdade de cada homem os primeiros instrumentos de sua conservação, como se comprometer sem se prejudicar e sem negligenciar os cuidados que deve a si? Esta dificuldade, trazida ao meu assunto, pode ser enunciada nestes termos: "Encontrar uma forma de associação, que defenda e proteja com toda a força comum a pessoa e os bens de cada associado e pela qual cada um se uniria a todos, obedecendo, entretanto, só a si mesmo e permanecendo tão livre 
quanto antes". Tal é o problema fundamental ao qual o contrato social fornece a solução (ROUSSEAU, 2008, p.29).

O contrato firmado era mais que plurilateral, sua característica é de contrato pluriétnico. Os interesses e tarefas de proteção da terra ocupada não poderiam ser realizadas por indivíduos isolados, então se uniram as três etnias em torno de um objetivo comum e a manifesta declaração de vontade nesse sentido consagrou o contrato ali consensuado. A fonte de obrigação passou a ser o contrato firmado entre as etnias.

O Guarani sempre teve alianças com outros povos, por isso não lhe foi estranho sentar-se com o Kaiowa e Terena para compor a nova aliança. Cada chefe de família grande cuidaria do seu núcleo familiar, mas estariam sujeitos a uma ordem maior que ficou na pessoa do capitão, auxiliado por certo número de conselheiros, estes escolhidos dentre o Guarani, Kaiowa e Terena, para que junto com os chefes de família pudessem discutir os problemas da comunidade e como solucioná-los.

A esse fato de associar-se em prol da sobrevivência e abrir mão de prerrogativas individuais, assinala Locke:

Sempre que certo número de indivíduos se reúne em sociedade, de tal modo que cada um abra mão do próprio poder de executar a lei de natureza, transferindo-o à comunidade, nesse caso, e somente nele, haverá uma sociedade civil ou política. E tal ocorre sempre que certo número de homens, no estado de natureza, se associa para constituir um povo, um corpo político sob um governo supremo, ou então quando qualquer indivíduo se junta ou se incorpora a uma comunidade já constituída; com isso autoriza a sociedade ou, o que vem dar no mesmo, o poder legislativo dela, a elaborar leis para ele, dentro da exigência do bem da sociedade, sendo que poderá ser solicitado o seu auxilio para a sua execução, como se fossem decretos dele mesmo. Dessa forma homens saem do estado de natureza para entrarem no de comunidade, estabelecendo um juiz no mundo com autoridade para deslindar todas as demandas e reparar os danos que atinjam a qualquer membro da comunidade; juiz esse que é o legislativo, ou os magistrados por ele nomeados. E sempre que existir qualquer número de homens que, malgrado associados, não tenham constituído tal poder superior para o qual apelar, estes ainda se encontrarão em estado de natureza (LOCKE, 2009, p. 62-63).

Ao tempo da constituição do contrato interétnico, os mais velhos da comunidade relatam que o número de habitantes oscilava entre 250 e 300 pessoas. O SPI, posteriormente à demarcação das reservas indígenas, instituiu a figura do capitão em todas elas, que passou a ter a função de porta voz e intermediação em todos os Posto Indígenas e, como chefe político de toda a comunidade, era auxiliado por um sargento e os demais eram como soldados.

Tradicionalmente, o líder político (mburuvixa) era aclamado devido à necessidade de se enfrentar uma situação 
específica, como no caso das incursões guerreiras. No entanto, passado este momento, voltava-se à chefia dos de família grande. A autoridade que passava a ser respeitada era o nhanderu e a nhandesy.

A função do cargo de capitão perpassa por uma lógica diferente da sóciopolítica tradicional, lembrando que naquele momento a lógica militar dos ex-combatentes da guerra prevalecia, pois tanto o Terena quanto o Guarani estavam saindo das fileiras do exército.

O conselho de caráter político auxiliava o capitão em como agir diante do problema que surgisse na comunidade, das desavenças que sempre ocorriam. Estas deveriam ser muito bem resolvidas. Mesmo o Guarani sendo de índole pacífica, valendo-se da diplomacia para resolver os seus problemas, seus ânimos guerreiros faziam emergir a sua face oculta: a da vingança, contra os inimigos como entre os próprios da comunidade. Não vingar um morto era equivalente a se esquecer quem se era, seria como alguém sem história, sem passado, é ser ninguém no presente e aniquilado para o futuro.

O perdão nem sempre era uma virtude presente no cotidiano. O Guarani era muito amigo da guerra, embora procurasse evitá-la. Mesmo buscando valer-se da diplomacia, não fugiam daquela. A morte era apenas um detalhe, desde que fosse uma morte heroica, ela era desejada. Quando eram feitos prisioneiros pelos inimigos, preferiam ficar e morrer e não fugiam amparados na certeza de que a sua família, todos do seu tekoha o vingaria, que seria lembrado nas histórias contadas nas festas religiosas, seu nome seria perpetuado nas narrativas, faria parte do rol de heróis guerreiros. A honra e prestígio pósmortem lhes fascinavam.

O status de ser guerreiro rendia ao indivíduo grande estima aos olhos da comunidade. Sendo uma posição de honra, não temia a morte e o grande orgulho era capturar ou levar à morte um grande número de inimigos. Por outro lado, o indivíduo covarde poderia ser até mesmo excluído da comunidade, tornava-se a vergonha de todos, pois era inadmissível alguém negar seus signos de pertença, dizer-se Guarani e não ter coragem para enfrentar o inimigo. Os meninos desde cedo já recebiam uma educação militar preparatória para todas as situações de adversidade. Algumas danças eram próprias para preparar o físico dos jovens, para ficarem leves, rápidos e mortais no ataque.

Ocasionalmente nas disputas pessoais, as lutas eram brutais, violentas, e os envolvidos valiam-se do que estivesse ao alcance das mãos para atingir o adversário, quase sempre havia a morte de um deles. Por esta razão as regras que regiam o direito 
Guarani eram severas, indo de uma simples advertência, até o chicoteamento em público.As infrações às regras morais puniam-se socialmente e, em alguns casos, com severidade. Se o ato praticado fosse grave poderia ser convocado o amandaje, porém sendo de uma gravidade extrema, seria convocado o aty guassú. O castigo por infração moral é uma das constantes na religião Guarani, sendo frequente a exposição pública da pessoa que, ridicularizada, perdia o prestigio de avaete, passava a ser motivo de chacotas, piadas, brincadeiras, escárnio.

O Guarani é livre, não tem quem lhe dê ordens, porém é convencido de como deve ser a sua conduta. Esse ensinamento vem por meio das festas religiosas, onde era demonstrada a forma como o Guarani verdadeiro deve se comportar.

Até o período da iniciação, o (a) jovem recebe todos os ensinamentos de como é o ideal de conduta durante a vida adulta, sempre considerando o bem da comunidade, por isso é preparado para ser um adulto com direitos e obrigações. Respeitando a tradição, participava das festas, e tendo em conta o preceituado pela religião tornava-se membro efetivo da comunidade.

Os preceitos religiosos se confundem com o próprio direito. Em um mundo de significações entrelaçadas, é muito tênue a linha que separa um do outro, pois um dado fenômeno pode ter implicações no âmbito econômico, político, religioso e social.

A religião e o Direito Guarani não escravizam a pessoa, não a ameaçam, mas é o elo da sociabilidade que perfaz o círculo da dependência que um tem do outro, buscando um resultado que é o bem-estar da comunidade. O Guarani é um legítimo cumpridor de suas leis, procura ao máximo conter o instinto natural do ser humano em ser violento; acredita que tem duas almas: a alma humana que é pacífica e a alma animal, que é a causadora de todo tipo de violência e males; esta alma animal é que deveria ser controlada e cabia aos líderes religiosos a função de mantê-la sempre sob controle.

Quando ocorria de alguém sentir a sua alma animal manifestar-se, ele se afastava do convívio da comunidade para não lhes causar mal através de suas ações, pois a alma animal é despida de sentimento de justiça ou de qualquer outro sentimento ou discernimento inerente ao ser humano.

No entendimento de Susnik (188), para manter a ordem e a integridade em qualquer grupo humano, se faz necessário a presença de um parâmetro legal, com força suficiente para regulamentar as relações sociais, de forma que iniba os atos socialmente reprováveis.

Para Wolkmer: 
Toda cultura tem um aspecto normativo, cabendo-lhe delimitar a existência de padrões, regras e valores que institucionalizam modelos de conduta. Cada sociedade esforça-se para assegurar uma determinada ordem social, instrumentalizando normas de regulamentação essenciais, capazes de atuar como sistema eficaz de controle social. Constata-se que, na maioria das sociedades remotas, a lei é considerada como parte nuclear do controle social, elemento material para prevenir, remediar ou castigar os desvios das regras prescritas. A lei expressa a presença de um Direito ordenado na tradição e nas práticas costumeiras que mantêm a coesão do grupo social (WOLKMER, 1996, p. 17).

Todos da nova comunidade que se formava obedeciam às normas de convívio social instituída, sendo vital para o grupo a observação das regras do contrato interétnico; a sobrevivência dependia disso, não se colocaria em risco a integridade do grupo. Guarani, Kaiowa e Terena, unidos pelo bem comum de suas famílias; compromisso confirmado pela rede de alianças formada através dos casamentos.

O capitão estava ali para ser também a ponte entre a comunidade indígena e a comunidade dos brancos, bem como ser o responsável em manter a disciplina e a ordem, quando esta ultrapassasse o terreiro da família grande. Nem sempre a sua intervenção se fazia necessária, em muitos casos tudo se resolvia no âmbito da própria família, a menos que envolvesse outra família, nestes casos então ia ao conhecimento dos conselheiros e estes com o capitão resolviam a questão.

Por vezes o poder político, representado pelo capitão, encontrava a resistência do poder religioso, representado pelo feiticeiro, ou profeta de desgraças. Estes almejavam alcançar o poder por meio da coerção psicológica, por essa razão a pena prevista para esse tipo de delito era queimar publicamente o feiticeiro. Sua ação desestabilizava completamente a comunidade, dominada pelo medo do feitiço, o mal mais temido pelo Guarani ou Terena.

\section{A liderança política}

Não há consenso entre os antropólogos e os cientistas sociais, quanto à existência desse poder político nas comunidades indígenas. Alguns afirmam que o mesmo existe quando há o emprego da força e outros afirmam que existiu, está na coletividade, assim como no caso Guarani, isso fica perceptível na obra de (COLAÇO, 1999).

As relações internas que permitem a governabilidade, formando o sistema de liderança política, estão orientadas pelo mundo jurídico-religioso, pelas regras préestabelecidas, aceitas por todos e que devem ser respeitadas, para que assim o equilíbrio social não possa ser comprometido. Esse poder está na e com a comunidade, onde cada 
família grande é um grupo de pressão. Não havendo a centralização de poder, o capitão poderia ser substituído a qualquer momento, se este não estivesse cumprindo com as suas obrigações sociais e jurídicas.

Segundo Roberto Aguiar:

O poder não é algo que possa ser guardado e transferido, pois não é algo material, palpável. Se o poder é resultante da relação entre as pessoas, não é possível refletir-se sobre o poder senão sob o signo da alteridade, é uma relação entre homens, uma relação temporal, mutável, e sensível que pode ser rompida a qualquer momento (AGUIAR, 1990, p. 50).

As relações se tornavam complexas por serem três etnias com um só capitão, pois os indivíduos não são iguais mesmo em se tratando da mesma etnia. As relações sociais, entretanto, não se alteravam tendo em vista o bem-estar de todos. As famílias grandes ocupavam áreas estratégicas, para garantir a segurança da comunidade, de modo que havia alguns quilômetros que separavam os núcleos familiares. Esta era também a estratégia para que todo o espaço que intentavam ser seu por ocupação fosse defendido de possíveis ameaças.

Salienta RAMOS que há distinção entre "indivíduos e ou categorias de indivíduos":

Existem sempre diferenças entre homens e mulheres, entre jovens e velhos, entre adultos e crianças. Sobre essas diferenças físico-sociais é possível construir diferenças sociopolíticas, o que geralmente ocorre: os homens tendem a ter um maior domínio sobre as mulheres do que vice-versa, e os mais velhos sobre os mais novos. Há, também, consideráveis distinções em personalidades e habilidades pessoais; há os bons e maus xamãs, os bons e maus oradores. Essas diferenças psicossociais podem também se tornar a base para diferenciações sociopolíticas. (RAMOS, 1988, p. 66).

Os chefes políticos sempre tiveram mais obrigações que privilégios, quanto mais bens (alimento) possuíssem, mais teriam que repartir com os demais membros do tekoha. A obrigação de dar pressupõe a obrigação de receber e receber se converte na obrigação de dar. A mesquinhez era o hábito mais reprovado entre o Guarani, o indivíduo sovina não era bem quisto pela comunidade, podendo ser excluído do convívio de todos.

De acordo com Arendt:

O poder só é efetivado enquanto a palavra e o ato não se divorciam, quando as palavras não são vazias e os atos não são brutais, quando as palavras não são empregadas para velar intenções, mas para revelar realidades, e os atos não são usados para violar e destruir, mas para criar relações e novas realidades (ARENDT, 2001, p. 189).

As qualidades exigidas de um chefe, que o legitimavam no cargo, era a idade, coragem, experiência, generosidade, boa oratória, capacidade de organização, ser bom caçador, bom pescador, não ser preguiçoso, ser bom estrategista e um bom agricultor. 
Estas qualidades eram indícios de que poderia ajudar a comunidade nos seus interesses. Sendo um bom orador, seu poder de persuasão o faria mais prestigiado ainda, na verdade não havia um poder48, mas prestígio entre os da comunidade, pois o Guarani não se presta a ser subordinado de alguém; desde a educação dada as crianças, a repressão é inexpressiva e quando adulto não há quem o obrigue a obedecer, ele ouve e segue o líder porque foi convencido pelo poder das palavras, não da imposição ou obrigação.

O próprio prestígio resulta das ações do indivíduo e o resultado dos seus feitos, não deixa der ser uma expressão de força; quem o possui domina, influi, manipula. Esse prestígio-influência pode ter diversas fontes, podendo ser econômica, política, religiosa e, no caso guarani é político-religiosa.

Dentre as funções do líder político destaca Martins:

Cabia-lhes dirigir os empreendimentos comunais como abrir as clareiras na mata em que se fariam as roças, bem como as caçadas coletivas e a construção das malocas. (...) repartir entre as famílias nucleares os lotes de terreno obtidos através da derrubada da floresta, conduzir habilmente as relações externas do grupo e manter a paz e a harmonia interna (MARTINS, 1991, p. 205).

Já Foucault corrobora que:
Os códigos fundamentais de uma cultura - aqueles que regem sua linguagem, seus esquemas perceptivos, suas trocas, suas técnicas, seus valores, a hierarquia de suas práticas - fixam, logo de entrada, para cada homem, as ordens empíricas com as quais terá de lidar e nas quais terá de se encontrar. Já em outra extremidade de pensamento, teorias científicas ou interpretações de filósofos explicam por que há em geral uma ordem estabelecida e não a outra (FOUCAULT, 1999, p. 16-17).

Nessa relação entre o chefe político e a comunidade, havia o pressuposto de que o primeiro tivesse alguns privilégios, entre os quais o de ser auxiliado na sua lavoura pela comunidade, para que assim pudesse ter em abundância e ser mais generoso ainda na distribuição de alimentos. A função de chefe político não era hereditária, qualquer um podia se candidatar, para ser eleito bastava ter as qualidades acima enumeradas e, claro, ser aceito pela comunidade.

$\mathrm{Na}$ rede de relações de poder o Nhanderu era de vital importância, acontecendo os casos de feitiçaria ou ainda disputas via mundo espiritual (feitiços), somente ele poderia dizer quem estava certo ou errado ou ainda sua obrigação era desfazer o feitiço. $\mathrm{O}$ chefe político podia também ser líder religioso, nestes casos o poder estava solidificado na esfera espiritual e política; quando isto ocorria quase sempre este ficava até o fim de seus dias, nas duas funções. 
O conselho dos anciãos ou o conselho dos chefes de família grande constituíam a outra forma de poder, funcionavam como uma instância consultiva e informal, suas deliberações auxiliavam o líder político em como conduzir a comunidade, resolver os problemas do cotidiano, quaisquer que fossem. Formavam a instância normativa e apelativa. Cabia-lhes a função de moderadores, quando das acaloradas discussões (dissensão entre as partes). Com os líderes políticos, estabeleciam as compensações pelas perdas sofridas (roubo, furto, negligência, feitiço) e as indenizações devidas (fogo provocado, animais na lavoura, trocas não cumpridas), para evitar vinganças futuras e a falta de reciprocidade.

A organização política era democrática. O poder conferido ao líder político vinha da comunidade e para a comunidade, na máxima da democracia "o governo do povo, para o povo e pelo povo." A autoridade do líder era frágil, seu respaldo estava na vontade da comunidade em querêlo como seu representante.

Hodiernamente a liderança política está concentrada, o chefe de um tekoha é exclusivamente político na pessoa do capitão, devido a influências culturais sofridas ao longo dos séculos e porque se separou o poder temporal do poder religioso. Pode ainda ser somente líder espiritual.

\section{A alteridade}

Desde o primeiro contato com o europeu se discute se os habitantes do novo mundo possuíam direitos, alma ou se eram gente. Sempre vistos como uma cultura incapaz, nascendo aí a problemática jurídica de como regulamentar as relações sociais entre conquistador e conquistado. Pululavam os conflitos de interpretação sobre quem seriam os índios. Eram gente? Possuíam direitos ou não?

Importante observar na atualidade que, dada a visibilidade política que as populações indígenas vêm conquistando, novas reflexões devem ser feitas, estas perpassam cada vez mais pela necessidade de se reconsiderar a maneira de pensar, a visão que a sociedade não indígena tem das sociedades indígenas. Os velhos estigmas devem ser superados, para somente assim se ter novos marcos de como conceituar o outro. No entender de Stefanes Pacheco (200), Os pressupostos para se pensar a questão indígena vão além das oposições entre vencedores ou vencidos, dominantes e dominados, que acabam deixando para as sociedades indígenas apenas dois papéis, os de vítimas de aniquilação ou de mártires da conservação da cultura.

Se alteridade implica colocar-se no lugar do outro, ouvir o outro como seu igual, reconhecê-lo, embora diferente, isso nunca 
aconteceu durante o período da conquista da nova terra.

\section{Para Pierre Clastres:}

É necessário aceitar a idéia de que a negação não significa um nada e de que, quando o espelho não nos devolve a imagem, isso não prova que não haja nada a observar (CLASTRES, 1990, p. 16).

Para se compreender o outro, que nesse caso é o indígena, faz-se necessário entender o conceito de direito, justiça, da reciprocidade por ele aplicada, para assim poder se ter o olhar um pouco além do terreiro da casa e se adentrar na sua cosmovisão, na sua religião. São os seus preceitos que o moldam. Essa característica Gilissen chama de "indiferenciação".

Hodiernamente, o problema continua em se saber se determinado indivíduo é ou não indígena. É ou não sujeito de direitos principalmente em relação à terra de ocupação tradicional. É aldeado ou urbano; de vivência tradicional ou "aculturado;" puro ou "mestiço." Não se atenta para o fato de que os povos indígenas têm suas próprias formas de pensar a política. Insurgem com estes modelos idealizados para si pelo outro, com isso surge o estigma, estereótipos, que faz os indígenas serem vistos com desdém, irritação, como estorvo, bêbado, vagabundo, preguiçoso.

Pressupõe-se que lugar de índio é nas matas, nas aldeias, caçando, pescando, que é o que índio de "verdade" sabe fazer, e não envolvido com questões políticas que exigem cumprimento de seus direitos.

Não se atentou para o fato de que os povos indígenas constroem seus processos de autonomia, têm seus projetos de futuro pensados a partir de sua cosmogonia, não limitados somente pela preservação cultural, mas reivindicando espaço próprio de discussão, de sua participação na construção da nação da qual faz parte.

\section{É sedimentado na antropologia o fato} de que a análise da cultura deve ser norteada pela tradição e memória, induzindo a ideia de imutabilidade de usos e costumes, como se a cultura não fosse dinâmica, impulsionado pelo pressuposto de que em contato com o branco determinada cultura estaria em risco de perder certas características de seu modo tradicional de ser, resultando daí uma aculturação, resultado da fricção interétnica (CARDOSO DE OLIVEIRA, 1996).

Deve-se levar em conta, entretanto, a reinterpretação da cultura que esses atores promovem para estar e conviver com o meio em que estão inseridos, seja urbano ou rural. As construções e desconstruções que os indígenas, entre os quais o guarani, promovem em relação as suas representações de cultura e da cultura do outro, ora acolhendo, ora rejeitando, não faz dele mais ou menos Guarani. Os esquemas culturais são reordenados de acordo com os 
acontecimentos históricos pelos indígenas, conforme a sua cosmologia, fato que vai aos poucos refletindo na sua organização social e nas relações interétnicas.

Diante dessa dificuldade e complexidade multicultural, assim se expressa Boaventura de Sousa Santos:

A construção de um conhecimento multicultural tem duas dificuldades: o silêncio e a diferença. O domínio Global da ciência moderna como conhecimento-regulação acarretou consigo a destruição de muitas formas de saber, sobretudo daquelas que eram próprias dos povos que foram objecto do colonialismo ocidental. Tal destruição provocou silêncios que tornaram impronunciáveis as necessidades e as aspirações dos povos ou grupos sociais cujas formas de saber foram objecto de destruição. Não esqueçamos que sobre a capa dos valores universais autorizados pela razão foi de facto imposta a razão de uma "raça", de um sexo e de uma classe social (SANTOS, 2000, p. 30).

A construção e reconstrução da pessoa Guarani são influenciadas pelos acontecimentos ao seu redor, porém os princípios valorativos são de sua matriz religiosa. Calcado na sua espiritualidade, o seu alicerce é a sua cosmologia. Essa construção ocorre também pelo olhar do outro, não que isso não influencie internamente na comunidade, mas projeta um indígena estigmatizado.

Então, se têm dois tipos culturalmente construídos, dois olhares sobre a mesma pessoa: o indígena que reinterpreta valores externos e enriquece a sua cultura (lógica indígena) e o indígena visto pelo olhar de quem está fora da terra indígena, da vivência cotidiana, que o vê como aculturado (lógica racional do não índio). A reprodução pelo indígena de suas categorias culturais específicas é constantemente reelaborada na contemporaneidade, no parentesco, no sistema de chefia e na economia de reciprocidade. Isso é mais perceptível nas comunidades que estão em intenso contato com o não indígena, e nos casos onde a cidade veio até o indígena.

Há uma busca pelo que é bom e se no momento seguinte isso não é mais interessante, o lógico é deixar para trás, desviar-se do que não é mais interessante. Essa postura que Viveiros de Castro chamou de Inconstância da alma selvagem:

Essa proverbial inconstância não foi registrada somente para as coisas da fé. Ela passou na verdade a ser um traço definidor do caráter ameríndio, consolidando-se como um dos estereótipos do imaginário nacional: o índio mal-converso que, à primeira oportunidade, manda Deus, a enxada, ao diabo, retornando feliz à selva, presa de um atavismo incurável (VIVEIROS DE CASTRO, 2002, p. 186-187).

Lembrando que essa forma de pensar e comportamento são aplicados aos Guarani. Em todo o contato entre povos diferentes, se não forem respeitados os princípios básicos 
de existência das sociedades envolvidas, haverá uma relação desigual na convivência que se quer estabelecer, entre dois povos distintos no seu modo de entender o mundo. A lógica é que se busque a estabilidade e segurança nas relações que não podem primar pelo etnocentrismo, muito menos por verdades absolutas; caso isso venha a ocorrer, haverá um gritante desrespeito aos direitos humanos. A capacidade de conviver com o outro que é diferente deve ser mais que uma simples tolerância, para uma boa convivência deve haver o respeito, caso contrário se terá uma intolerância velada.

A identidade e alteridade caminham juntas, assim como a semelhança/diferença, estão sempre se acercando de comparações entre uma cultura e outra, o que quase sempre redunda em conflitos de olhares, juízo de valores dissonantes, mesmo porque as pessoas são diferentes. Afirma Moreira que a comparação é uma imprudência metodológica, podendo se apresentar ingênua, enganosa e corromper o que se está observando, quando o que se quer de imediato é encontrar diferenças ou contrastes.

Cada qual com os seus valores de acordo com o meio cultural em que nasceram e foram educados. Sempre existirá o diferente, dois juízos sobre um mesmo fato, ainda mais se tratando de dois povos diferentes, o que não impede o conciliamento de ideias, desde que as duas partes estejam dispostas ao diálogo.

Para Damatta (1987), o problema reside em que a expressão cultural quando se aproxima de alguma forma de comportamento e de pensamento diferente traz a classificação dessa diferença por meio da hierarquia, por consequência vem à exclusão. A cultura do outro passa a ser usado como forma discriminatória, ou pior ainda, como índice de desvio ou de atraso, tão somente pelo fato de se ter tradições diferentes e desconhecidas.

Nesse sentido afirma Boaventura de Souza Santos:

A segunda dificuldade do conhecimento multicultural é a diferença. Só existe conhecimento e, portanto, solidariedade nas diferenças e a diferença sem inteligibilidade conduz à incomensurabilidade $\mathrm{e}$, em última instância, à indiferença. Daí a necessidade da teoria da tradução e do que eu designo por hermenêutica diatópica que uma necessidade, uma aspiração, uma prática em numa dada cultura pode ser tornada compreensível e inteligível para outra cultura. $\mathrm{O}$ conhecimento-emancipação não aspira a uma grande teoria, aspira sim a uma teoria da tradução que sirva de suporte epistemológico às práticas emancipatórias, todas elas finitas e incompletas e, por isso, apenas sustentáveis quando ligados em rede (SANTOS, 2000, p. 30-31).

É exatamente essa incompreensão que acarreta equívocos, ser visto sob o prisma 
da diferença é algo desejável, porém ser analisado sob a ótica da diferença para se ter a diferença é o primeiro passo para se aniquilar a isonomia de tratamentos e do próprio direito, considerando a diversidade de povos indígenas no Brasil.

\section{O território}

O território para o indígena tem a ver com seu espaço existencial, onde assinala o meio ambiente criador da sua identidade, das suas relações sociais, onde vive ou tenta viver plenamente a sua cultura, desenvolvendo a sua política, os seus meios econômicos, culturais e religiosos. Não é apenas o lugar que serve para morar, plantar roças, caçar, pescar. É também o espaço da construção de redes e laços de parentesco. É o local onde estão constantemente revivendo os seus costumes, enfatizando aspectos importantes da sua cultura. É onde o mundo natural está carregado de significações, que influencia diretamente nas relações sociais; é nesse espaço físico que são tramados os fios da rede de significados sustentáculos da vida. Os símbolos que definem a sua cosmovisão, os usos e costumes que desenham as particularidades e especificidade de sua cultura. É a referência que ampara os valores e formatam os cânones de sua cognição, definidora do seu modo de ser, refletindo em toda as suas práticas diárias e delineiam a sua sociedade. Por outro lado o território assume as feições da construção social e cultural do povo que o ocupa.

É onde estão enterrados os seus antepassados, representando o seu poder sócio- cultural. É onde cada planta, animal, pedra, tem o seu significado. É o ambiente onde desenvolvem as suas formas de pensar, agir e ver o mundo. $\mathrm{O}$ território é todo o conjunto de seres, espíritos, bens, conhecimentos, usos e tradições. É onde se articula define e mobiliza as pessoas em torno de um bem comum, garantindo a vida individual e coletiva. É sempre a referência à ancestralidade, à formação de sua cosmologia e de sua rede de significações, onde passado e presente estão em constante sintonia, vivos e mortos habitam o mesmo espaço, onde estão os heróis que povoam as histórias, sejam eles vivos ou mortos, como interpreta Luciano (2006).

O território compreende todo o espaço de suas caminhadas de exploração da natureza, aí inclusos a área de caça, pesca, moradia, casa, roça e cemitério. Para o indígena, na natureza os visíveis e invisíveis se comunicam e estão sempre juntos, assim como humanos e não humanos, estão em constante comunicação.

O território é configurado pela malha dos caminhos terrestres e fluviais, que se comunica com outras terras, leva para a 
morada dos seres mitológicos, para os locais de cerimônia, onde se concretiza os fundamentos do seu ser-estar nesse mundo.

Do lugar onde se constrói a moradia, se estende o olhar da forma como o território vai ser aproveitado. É o planejamento de uso por área, o local da coleta, das lavouras, da caça, da pesca, de extração de materiais para construções de casas, artesanatos e os seus artefatos. São círculos ou áreas classificadas de acordo com o solo e com os recursos naturais que apresenta.

A natureza de relacionamento do indígena com a terra é de filiação. A terra é sua mãe generosa que tudo oferece aos seus filhos, em troca requer respeito, que é premissa de vida. A terra é sagrada, nela está a morada dos espíritos de seus ancestrais, ela não é somente meio de produção de alimentos, mas é parte do próprio indígena. Como ser provido de alma, a terra também adoece e somente os nhanderus podem curála; sua doença é um mal espiritual e quando ela adoece, todos os que dependem dela adoecem juntos.

A terra, no sentido que é usada cotidianamente, é diferente do território; é somente aquela parte que foi demarcada, que faz parte do território. Está dentro do território, mas é menor que este. No Estado de Mato Grosso do Sul, as terras demarcadas não correspondem ao espaço onde eram os antigos tekohas, mas sim onde os funcionários do Serviço de Proteção aos Índios achavam por bem demarcar, não havia nenhum critério antropológico, estes observavam se havia água, madeira, caça, pesca (isso nem sempre correspondia à realidade da terra demarcada), e para lá amontoavam os indígenas que se encontravam em áreas de fazendas.

\section{A reserva indígena de Dourados-MS}

Instituída em 1917, pelo Decreto 401 do Presidente do então Estado do Mato Grosso, a Reserva indígena de Dourados tem suas terras demarcadas em 1925, totalizando 3.539 hectares, hoje divididos em dois tekohas: Jaguapirú e a Bororó.

Os critérios utilizados pelos funcionários do Serviço de Proteção ao Índio (SPI), responsáveis pela escolha e demarcação da terra, no geral não levavam em conta o habitat tradicional indígena, se a terra a ser demarcada era ou não de agrado dos indígenas futuros moradores da terra, nem mesmo, se aquela terra era ocupada por indígenas.

Alguns funcionários do órgão tutor do início do século passado tinham ao menos a preocupação com a qualidade da terra a ser demarcada, a salubridade e vias de comunicação. No caso da Reserva de 
Dourados, já havia os moradores pactuantes do contrato interétnico, a terra era de excelente qualidade, com matas virgens e abundantes em madeira de lei, bons mananciais, ainda que desprovida da presença de um rio.

No início não havia a divisão em Jaguapiru e Bororó, isto somente ocorreu depois de uma batalha contra os fazendeiros e a polícia da época, chamada de captura; neste confronto o primeiro a tombar foi um indígena Guarani chamado Antonio Bororó, em homenagem a ele e por ter ocorrido à luta na parte oeste da terra, esta passou a se chamar Bororó.

A outra metade da terra passou a se chamar Jaguapirú, também em decorrência do conflito armado. Foi nela que aconteceu o segundo confronto dos fazendeiros, a polícia (captura), contra os indígenas habitantes da terra.

Quando do confronto, a estratégia adotada foi de um primeiro grupo dar combate ao invasor branco na parte oeste do tekoha e depois fingir estar fugindo e levar o invasor para uma armadilha, onde estava a outra metade da força de resistência indígena. No entanto, quando os indígenas que "batiam em retirada" chegaram ao local combinado, não encontraram ninguém.

Ao findar a batalha e expulsos os fazendeiros, o capitão indígena ordenou a um dos seus verificar o que houve com os aliados que deveriam estar ali; este retornando disse: “daipore ma'ave, ahopama. Opytante peteín jaguápiru’í ojeliava horcon'pe.” (não há mais ninguém, foram todos embora. Ficou somente um cachorrinho magro amarrado no esteio do acampamento).

Daquele dia em diante, a parte leste do tekoha passou a ser chamada de jaguapirú. É sobre o direito de propriedade vigente nesta terra denominada de Reserva Indígena de Dourados que a dissertação discorrerá.

\section{Reflexões limiares}

O que está exigindo reflexão e esforço dialético e hermenêutico é o embate do novo (moderno), com o velho (tradições) ou o que permanece e o que muda? Foi exatamente com essa preocupação que a dissertação foi desenvolvida, embora tenha sido uma construção coletiva da qual participaram as mais diversas lideranças com sugestões de como escrever; ela não se direciona a indígenas, mas também aos não indígenas, portanto deveria ser de fácil assimilação. Ademais, a abordagem do assunto aqui tratado é desaconselhada pelos mais velhos, mesmo diante da necessidade de se falar sobre tal, o que dificulta ainda mais a construção do raciocínio sobre o Direito Guarani. 
A outra dificuldade está em como costurar esses princípios quando o Kaiowá e Guarani têm usos e costumes que por vezes são similares, mas não iguais. A construção da escrita passou pelo breve histórico de como se iniciou a RID, em razão de muitos pesquisadores se equivocarem na afirmação de quem começou a ocupação da terra que hoje é o tekoha. Tal confusão acirra as desavenças internas agravadas por uma tendência a ser partidário de uma etnia em detrimento de outras duas que formam a atual população do tekoha.

Em toda comunidade indígena, mesmo sendo pequena, haverá dissensões e diferenças de pensamento, porem quando isso é tratado pelos próprios membros, há como se consensuar uma solução; ainda que haja uma fragmentação da comunidade em duas, tem-se uma solução para o problema. Sempre haverá conflitos, pois na própria RID as três etnias foram instigadas por influencias externas a esquecer o contrato interétnico e atropelar as convenções internas há muito consensuadas.

Partindo do princípio constitucional de que todos são iguais perante a lei e que nos dias atuais é primordial que se atenha à função social, seja da propriedade ou da norma, bem como se deve, obrigatoriamente, ter a ética como princípio para se obter o fim almejado, que é alcançar justiça, justiça social ao aplicar e interpretar a norma, o Guarani hoje está vivendo em um limbo jurídico devido à interferência que transformou o dia a dia comunitário, agravando o que se tinha em velado controle.

No amanhã talvez não haja mais nada a compartilhar com os filhos senão a herança da esperança, para que possam ser homens verdadeiros, se não o forem segundo os usos e costumes e se a tradição não imperar; que o sejam não com coração de pedra, mas despidos da malícia negativa e que tenham ao menos solidariedade humana; que a alma humana esteja prevalecendo, não abrindo brechas para que a alma animal do guarani seja provocada, e com isso venha causar males a outrem ou desencadear novamente o surto de suicídios. Os ameríndios são dotados de cosmovisão diferente e seus valores trazem imanente o pulsar da mãe natureza e arraigados os seus sentimentos de um "selvagem" (assim rotulado pelo então civilizado), por pensamentos como o direito à vida livre, em harmonia, e mesmo não possuindo leis sistematizadas e desprovidos de Estado, viviam harmoniosamente com a natureza e seu próximo de etnia.

Para alcançar essa compreensão de vida é preciso ter claro a axiologia da alteridade e não se primar pelo etnocentrismo, mas atentar para o outro que também é sujeito de Direito, como qualquer cidadão brasileiro. O indígena não mais espera o direito chegar até ele, mas provoca o Estado para que cumpra as 
previsões constitucionais e os tratados internacionais do qual o Brasil é signatário.

A cultura, as tradições, os usos e costumes são vivos, transformam-se com o tempo, adaptam-se, são um gigante mutante, vestem-se de novas roupagens, mas a essência é a construção milenar da cosmovisão. A cultura do passado encontrase em museus e bibliotecas, a de hoje é recriada dia-a-dia. Dessa forma, a subalternidade ou imposição é algo a ser corrigido. A relação do Estado brasileiro com a questão indígena é cumprir a previsão constitucional, demarcando terras, sem se ater à tutela, mas atentar para o protagonismo indígena, como ator e sujeito de direito. $\mathrm{Na}$ Reserva Indígena de Dourados, essa vontade e liberdade não são respeitadas, há uma intromissão explícita externa. Houve três protagonistas em cena: FUNAI (Fundação Nacional do Índio), MPF (Ministério Público Federal), Executivo Municipal e um mero figurante: o indígena. Há contradições, ambiguidades nas relações, incoerências destoadas da pluralidade étnica, da diversidade de valores, da alteridade, da dignidade humana.

Dessa forma, discorremos sobre a atuação do MPF, situando o ápice no ano de 1998, quando estourou a revolta interna e tudo parou. Nos confrontos ninguém veio a óbito, mas houve um grande número de feridos e a consequente expulsão de muitas famílias. Dada a previsão constitucional, frente a mais nova e urgente face do Direito, que é a função social, relata-se no campo real suas repercussões junto à comunidade indígena de Dourados; a indagação que fica é se há ou não uma função social nas ações do MPF. Essa situação não é nova para o Guarani, afinal o português e o espanhol sempre se valeram das dissensões internas para destruir o povo, atribuindo mais direito a um e achacando a outro.

No passado, havia como fugir para a floresta, agora não há mais essa possibilidade; resta como solução formar as aldeias urbanas como recurso para fugir das intromissões externas nos costumes e usos da comunidade. O Aty Guassu tem se tornado na atualidade para o povo Guarani um momento em que é possível reinterpretar seus direitos internos e reafirmar seu modo de ser perante a sociedade nacional. É o momento em que chama a atenção das autoridades para os problemas que assolam os tekoha e que não são levados em consideração no momento de se elaborar as políticas públicas, desmerecendo a hermenêutica e a dialética da construção cultural e social. Até bem pouco tempo o indígena não podia sair de sua terra sem autorização da FUNAI; hoje, participa de reuniões internacionais defendendo o seu direito, desafia os invasores de sua terra tradicional, enfrenta sem medo as forças repressivas das multinacionais, porque ele 
sabe que essa terra tinha e tem dono. O código do silêncio está sendo quebrado para que a sobrevivência do povo guarani seja fortalecida e possa seguir em frente com o seu modo de vida tradicional, porquanto o Poder Judiciário do Estado Brasileiro tem um total desconhecimento da organização do sistema jurídico indígena, seja ele qual for tanto de sua origem quanto de sua execução no âmbito das terras indígenas. Tal fato tem representado nas ações propostas a favor ou contra uma imposição da sociedade hegemônica, de sua forma de operar $o$ direito perante $o$ funcionamento da justiça indígena, desrespeitando a sociodiversidade e o pluralismo jurídico, seguindo a lógica positivista que neste caso tem caráter excludente de direito.

O direito indígena sempre existiu, continua atuante no tekoha, mesmo na clandestinidade; não é visto como sendo expressão de uma das tantas faces do Direito. Procura-se, com isso, apagar o som do grito de mais um excluído, da condição de cidadão brasileiro e sujeito de direito. Isso se reflete em como o Guarani agora vê a propriedade, em como vê a terra. A nova geração desconhece os valores da tradição, a cosmologia, a espiritualidade está sendo deixada de lado, por contadas interferências externas que exaltam outros valores. Criam novas tendências no modo de pensar fomentando o conflito geracional que se acentua no velho versus novo; o tradicional opondo-se ao escolarizado.

A transformação do espaço físico pelo homem não indígena no entorno das comunidades resultou na influencia, imposição e consequente submissão política; pior de tudo é a dependência de favores do Estado como a cesta básica, considerando que a terra não produz mais nada se não se utilizarem as modernas tecnologias de produção da agricultura moderna, tecnologia que não está a sua disposição. $\mathrm{O}$ ato de interpretar, aceitar ou reinterpretar o novo é o esforço que se faz nas comunidades para tentar antever o amanhã; essa reflexão considera as profecias do cataclisma enunciado há muito pelos Nhanderus. A reinvenção do novo com o velho é o caminho trilhado na esperança de que se possa continuar sendo o que sempre se viveu.

A Reserva Indígena de Dourados está sob um manto de problemas gravíssimos e quase insolúveis: a superpopulação agravada pelo alto índice de nascimentos e a vinda de outras famílias de outras localidades. O uso sistemático do solo o esgotou e ao desmatamento sobreveio a degradação ambiental; o uso intensivo de agrotóxicos tem provocado uma mudança de comportamentos em relação a pratica da agricultura, e põe em risco a saúde de todos. Emergem profundas transformações decorrentes do processo de perda da terra e dos recursos naturais, porém 
o impacto maior se faz sentir não somente na economia de subsistência, mas incide diretamente na organização social, política e religiosa. Os nhanderus enfatizam que o resultado dos males experimentados pelo Guarani advêm não somente do fato de que a terra está doente, mas das transformações ocorridas na forma como se está vivendo a espiritualidade, a prática religiosa.

A interferência externa não permitindo a aplicação do direito Guarani, promoveu a RID a terra de ninguém; não se tem segurança, a ponto de agora os capitães declararam toque de recolher devido aos altos índices de violência. A droga tem livre trânsito e roubos, furtos, estupros, assaltos, homicídios e bocas de fumo têm se tornado corriqueiros no cotidiano da comunidade. As polícias Civil e Militar não atendem aos chamados alegando não ter permissão legal para entrar e reprimir a violência; a policia Federal alega não ter pessoal e que sua tarefa é combater o narcotráfico, tendo em vista que Dourados é um corredor do tráfico. Delegados afirmaram: "entramos na aldeia somente para recolher cadáveres". E os que provocaram toda essa situação ficam na segurança de seus lares, fora da terra indígena e não ofereceram nenhuma contrapartida para solucionar o problema. Mais uma vez os fios que tramam a história conspiram contra o indígena e ela não deixou de ser escrita com sangue, ainda que inocente.

\section{Referências bibliográficas}

AGUIAR, R. A. R. de. Direito Poder e Opressão. São Paulo: Editora Alfa Omega, 1990.

ARENDT, Hannah. A condição humana. Tradução de Roberto Raposo. 10. ed. Rio de Janeiro: Forense Universitária, 2001.

CARDOSO DE OLIVIERA, Roberto. Índio e o Mundo dos brancos. Campinas:

UNICAMP, 1996.

CLASTRES, Pierre. A Sociedade contra o Estado. 5. ed. Rio de Janeiro: Francisco Alves, 1990.

BRASIL. Código Civil, Lei 10.406, de 10 de janeiro de 2002. 1. ed. São Paulo: Revista dos Tribunais, 2002.

BRASIL. Constituição da República Federativa do Brasil, de 5 de outubro de 1988.

Disponível em $<$ http://www.planalto.gov.br/ccivil_03/consti tuicao/constituição.htm>.

COLAÇO, Thaís Luzia. "Incapacidade" indígena, tutela religiosa e violação do direito guarani nas missões jesuíticas. Curitiba: Juruá, 1999.

DAMATTA, Roberto. Explorações: Ensaio de sociologia interpretativa. Rio de Janeiro: Rocco, 1987.

FOUCAULT, Michael. As palavras e as coisas: Uma arqueologia das ciências humanas. Tradução de Salma Tannus Muchail. 8. ed. São Paulo: Martins Fontes, 1999. 
LOCKE, John. Segundo Tratado Sobre o Governo. Tradução de Alex Marins. São Paulo: Editora Martin Claret Ltda, 2009.

LUCIANO, Gersem dos Santos. O Índio Brasileiro: o que você precisa saber sobre os povos indígenas no Brasil de hoje. Brasília: Ministério da Educação, Secretaria de Educação Continuada, Alfabetização e Diversidade; LACED/Museu Nacional, 2006.

MARTINS, Maria Cristina Bohn. Os Guarani e a economia da reciprocidade. Dissertação (mestrado em história- Estudos Iberos Americanos), Universidade do Vale do Rio dos Sinos, São Leopoldo, 1991.

OIT - Organização Internacional do Trabalho - Escritório no Brasil. Acessado em 17 de junho de 2018.

RAMOS, Alcida Rita. Sociedades Indígenas. 2. ed. São Paulo: Ática, 1988.

ROUSSEAU, Jean-Jaques. Do Contrato Social: princípios de direito político. Tradução de J. Cretella Jr. e Agnes Cretella2. ed. rev. da tradução- São Paulo: Editora Revista dos Tribunais, 2008.

SANTOS, Boaventura de Sousa. A crítica da razão indolente: Contra o desperdício da experiência. VI. São Paulo: Cortez Editora, 2000.

STEFANES PACHECO, R. A. Direito Indígena: da pluralidade cultural a pluralidade jurídica. In: Revista Tellus, Núcleos de Estudos e Pesquisas das Populações Indígenas- NEPPI, ano 6, número 11, outubro/2006, Campo Grande: UCDB, 2006.
SUSNIK, Branislava. Introdución a la antropología social. (âmbito americano). Assunción: Museu Etnográfico “Andres Barbero", 1988.

VIVEIROS DE CASTRO, Eduardo Batalha. O problema da afinidade na Amazônia. In VIVEIROS DE CASTRO, Eduardo Batalha. A inconstância da alma selvagem- e outros ensaios de antropologia. São Paulo: Cosac \& Nafy, 2002.

WOLKMER, Antonio Carlos. O direito nas sociedades primitivas. Fundamentos da história do direito. Belo Horizonte: Del Rey, 1996. 